\title{
Discrimination in Predicting Entrepreneurial Intentions of the Disabled Students in Nigeria
}

\author{
Dakung Reuel Johnmark \\ Faculty of Management Sciences \\ Department of Business Administration \\ University of Jos-Nigeria \\ reueldakung@yahoo.com
}

\author{
John Munene \\ Makerere University Business School (MUBS) \\ Kampala, Uganda \\ kigozimunene@gmail.com
}

\begin{abstract}
Entrepreneurship activities have impacted so much in the areas of job creation and economic growth which are widely recognized across the world. Hence, entrepreneurial intention is important in triggering venture establishment and has significant impact on the venture's success. The purpose of this article is to examine discrimination as a predictor of entrepreneurial intentions of disabled students. The study followed a descriptive survey where both quantitative and qualitative approaches were employed. About 230 questionnaires were distributed to disabled students across the tertiary institutions (Universities, Polytechnics and colleges) in Plateau State-Nigeria. Results reveal that discrimination, attitudes and perceived behavioural control positively influence entrepreneurial intentions of disabled students.
\end{abstract}

Keywords: Disability, Discrimination, Entrepreneurship, Entrepreneurial Intention.

\section{INTRODUCTION}

Entrepreneurship activities have impacted so much in the areas of job creation and economic growth which are widely recognized across the world (Kritikos, 2014; Valliere \& Peterson, 2009). Job creation through the establishment of ventures is seen to be initiated by entrepreneurs without reflex but intentionally because it helps in explaining the reasons why certain individuals choose to start a business (Krueger et al., 2000). Hence, entrepreneurial intention is important in triggering venture establishment and has significant impact on the venture's success and as such, offers strong validity for the start-up decision (Kautonen et al., 2013; Krueger et al., 2000; Davidsson, 1995). Selfemployment among people with disabilities (PWDs) is seen to be one of their motivations for business start-up and is recorded high in developed countries like UK and USA (Pagan, 2009; Kitching, 2014). This is supported by Viriri and Makurumidze (2014) who opined that for the fact that people with disabilities are stigmatized, discriminated and marginalized in every facet of life, they have a higher rate of self-employment. However, the decision to venture into business is seen to be low among people with disabilities (PWDs) in a developing country like Nigeria where the figures of unemployment have steadily risen peaking at $23.4 \%$ in 2014 (Udo, 2015; National Bureau of Statistics, 2015). This assertion is confirmed by scholars that just few PWD (18.1\%) in Nigeria are self-employed and many of them (about $81.9 \%$ ) are seen to be unemployed because of discrimination and exclusion (Global Accessibility, 2015).

To respond to the unemployment menace and further encourage entrepreneurship spirit, the Nigerian government initiated programmes through support agencies such as National Directorate for Employment (NDE) in 1987, National Poverty Eradication Programme (NAPEP) in 2001, Small and Medium Enterprises Development Agency (SMEDAN) in 2003 (Akhuemonkhan et al., 2013; Emmanuel et al., 2012; Olayinka 2010). However, the evaluation of these programmes in the area of addressing unemployment among the disabled youths confirms that the action plan was still lacking for not being tailored to the needs of PWDs (Egunsola, Dazala \& Daniel, 2012; Yoloye, 2008). Also, the 2007 entrepreneurship education programme launched in the Nigerian tertiary institutions excluded the disabled students (Onyilofor, 2014; Oladejo \& Oladejo, 2011).

Entrepreneurship intention (EI) is considered as the first step in business formation and one feature of the literature on entrepreneurs with disabilities is that the intentions for starting their own businesses are heavily rooted in negative motives since failure to find jobs is a key push factor for them to consider self-employment (Cooney, 2008; Lee and Wong, 2004). Consequently, Blanck et al (2000) 
identified discrimination as a negative (push) factor that influences entrepreneurial intentions of the disabled. On the other hand, Holub (2001); Harper and Momm (1989) argued that a number of positive (pull) psychological factors like independence, freedom associated with self-employment, innovation, perseverance, initiative and freedom from access-related obstacles may make it easier rather than harder for some PWDs to venture into their own businesses. However to East Midlands Development Agency (2009), PWDs make natural entrepreneurs and so the factors that trigger their entrepreneurship intentions are the same as for their non-disabled counter parts. Their argument anchors on the fact that people generally have a more entrepreneurial character and are innately entrepreneurial. So, depending on the triggering factors (whether personality-traits, contextual, motivational or personal background), they would eventually set up a business anyway.

Thus, this study sheds more light and overcomes the weaknesses of previous studies by anchoring our arguments on theoretical foundations (Social Disability Model and theory of Planned Behaviour) to establish the predicting role of discrimination alongside perceived behavioural control and attitude on entrepreneurial intentions among disabled students in the Nigerian tertiary institutions. The paper is organised into five (5) sections starting with the brief overview of the research study followed by the theoretical framework, reviewed literature and hypotheses, methodology, results and discussions, conclusions and recommendations.

\subsection{Theoretical Background}

For investigating discrimination in predicting entrepreneurial intentions of the disabled students in Nigeria, this study invokes Social Disability Model and Theory of Planned Behaviour.

\subsubsection{Social Model of Disability}

The Social Model of Disability (SMD) emphasizes that individuals with disabilities have struggled to live full and productive lives as independently as possible in a society laden with stigma, discrimination, attitudinal and environmental barriers (UPIAS, 1976; Finkelstein, 1980; Oliver, 1996 $\&$ Corker, 2000). Most theories assume that entrepreneurs are able people, thereby excluding the disabled. In the light of that, the disabled who have strong intention of becoming entrepreneurs always desire for inclusion that will enable them take risk, be resilient and have autonomy (Asch \& Fine, 1988). Hence, a number of PWDs (Helen Keller, Louis Braille, Henry Wood) have disproved the wrong assumptions about them by demonstrating to the world that there are abilities in disabilities through offering their full productive capacities, particularly in the area of job creation (Westphal, Bonanno \& Mancini, 2010).

\subsubsection{Theory of Planned Behaviour (TPB)}

The theory of Planned Behaviour (TPB) (Ajzen, 1991) and its underlying theories provide the theoretical and epistemological framework that attempts to explain all behaviours over which people have the ability to exert self-control. It is an extension of the theory of reasoned action (Ajzen \& Fishbein, 1980) made necessary by the original model's limitations in dealing with behaviours over which people have incomplete volitional control.

The central factor in the theory of planned behaviour is the individual's intention to perform a given behaviour. The theory emphasizes that individuals are rational in considering their actions and that decision is made under uncertainty. Rational decision implies that either optimum results are expected or decision making unit is aware of all the impacts and consequences (Basu, 1997; Eppen, 1998).

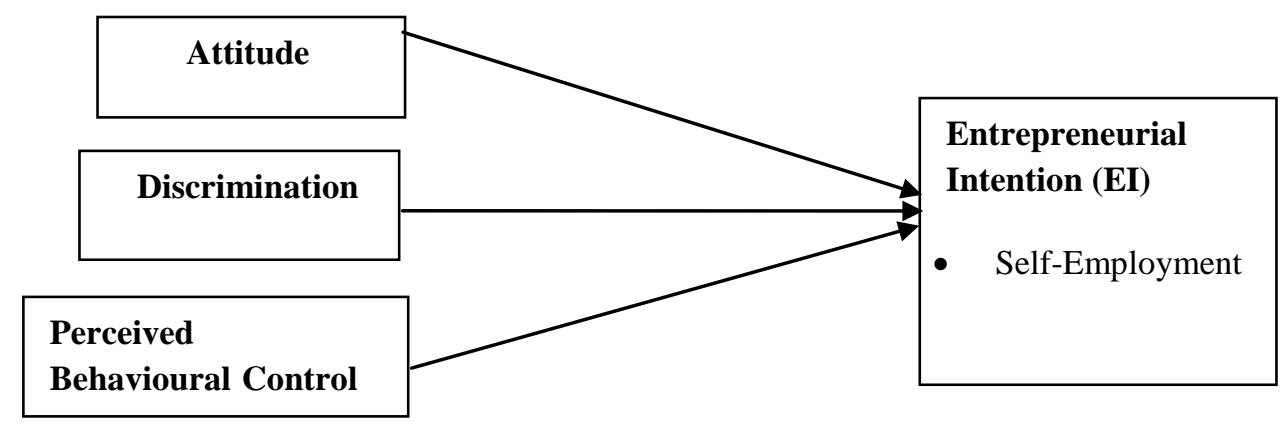

Fig1. Conceptual Framework

Source: Authors' conception from literature review 
By introducing "perceived behavioural control" to subjective norms and attitudes, TPB clearly explains the relationship between behavioural intention and actual behaviour. Widely used in social psychology and its applicability to the entrepreneurship domain, Ajzen's intentions-centred theory of planned behaviour is attractive, well grounded in theory, and robustly predicts a wide variety of planned behaviours.

Fig1 is a conceptual frame work highlighting inter-variable relationships in the study. Entrepreneurial intention is the dependent (criterion) variable. It is hypothesized that discrimination, attitude and perceived behavioural control (independent variables) explain changes in entrepreneurial intention. The relationship is shown by the model above.

\subsection{Literature Review and Hypothesized Relationships}

Extant research on entrepreneurial intentions suggests positive relationships between intentions and behaviour and between attitudes and intentions (Bird's model, 1988; Davidsson, 1995; Autio et al, 1997; Tounés, 2006). On the other hand there are few mixed findings regarding the effect of perceived behavioural control, discrimination and attitudes on intentions (Reitan, 1996; Krueger et al., 2000; Cooney, 2008). Additionally, these scanty findings relate to developed economies. Hardly enough empirical research has focused on developing countries, especially Nigeria - a fact that created a gap for this study.

\subsection{Concept of Disability}

Disability is a broad concept which covers impairments, activity limitations and participation restrictions. Participation restriction is a social problem that people encounter when involving themselves in life situations (WHO, 2014). Disability is a complex issue apart from being a health problem since it reflects the relationship between a person's body characteristics and the characteristics of the society to which he/she belongs to or lives in. Removing both environmental and social barriers will solve the problems that disabled people encounter (WHO, 2014). In general, PWDs are seen to be excluded from public services that indirectly discriminate against them by not including their needs (WHO \& World Bank, 2011). Furthermore, the attitudes of the society towards PWDs has led to them being negatively treated in areas such as (i) when strangers mock at them, (ii) employers discriminate against them, (iii), bus driver not supporting access needs of disabled passengers and (iv) school children intimidating their colleagues with disabilities.

Disability is also seen as a development issue with bidirectional link to poverty. Hence, Lamb (2009) observed that disability and poverty are positively related because increase disability may lead to increase in the risk of poverty and vice versa. This suggests that reducing poverty indirectly means reducing the risk of disability. Record has it that (WHO, 2014) over a billion people, about $15 \%$ of the world's population has some form of disability, and over $80 \%$ of them live in developing countries and about 22 (12.9\%) million in Nigeria. Besides, the disabled persons are diverse and heterogeneous but people generally discriminate against them by viewing them as wheelchair users, blind and deaf people.

\subsection{Entrepreneurial Intentions}

Intention, an immediate antecedent of behaviour is not performed mindlessly but follows reasonable and consistent behaviour-relevant information that is reinforced by rewards (Ajzen, 1991; Barringer \& Ireland, 2010). Entrepreneurial intention (EI) could be defined as willingness of individuals to perform entrepreneurial behaviour, to engage in entrepreneurial action, to be self-employed, or to establish new business (Dell, 2008; Dhose \& Walter, 2010). It means then that an individual may have potential to be entrepreneur but not make any transition into entrepreneurship unless they have such intentions. This is seen to be substantially more than merely a proxy for entrepreneurship. It is a legitimate and useful construct in its own right that can be used not just as a dependent, but as an independent and a control variable (Thompson, 2009). Recent empirical evidence confirms that entrepreneurial intentions seem to predict well future start-up behaviour and as such, offers strong validity for the decision (Kautonen et al., 2013). This is so because individuals do not start a business as reflex; they do it intentionally and not accidentally because entrepreneurial intention helps in explaining the reasons why certain individuals choose to start a business. Hence, entrepreneurial intention is an important factor in triggering new venture establishment and has significant impact on the firms' venture success, survival and growth (Krueger et al., 2000). By implication, intentional 
process often begins based on an entrepreneur's personal need, values, wants, habits and beliefs. Scholars empirically evidenced that entrepreneurial intention is a valid predictor for entrepreneurial behaviour as entrepreneurial actions always fall into the category of intentional behaviour. In addition, studying entrepreneurial intention provides valuable insights for researchers to understand entrepreneurial process and predict entrepreneurial activities in better way through identifying antecedents of entrepreneurial intention. Also, the intentions to be self-employed will eventually determine later entry into self-employment (Liñán, 2004; Kolvereid and Isaksen, 2006; Dell, 2008; Ismail et al., 2009).

\subsection{Attitude and Entrepreneurial Intention}

In order to understand how attitude influences entrepreneurial intentions, we started by adopting the Theory of Planned Behaviour (TPB) developed by Ajzen (1991). TPB model is important because of its detailed and consistent theoretical specification with the great amount of cross-disciplinary research explanations (Armitage and Conner, 2001; Sheeran et al., 1999). Attitude, being one of the core conceptually independent determinants of TPB refers to the degree to which a person has a favourable or unfavourable evaluation of the behaviour in question. Hence, the more positive an individual's perception is regarding the outcome of starting a business, the more favourable their perceived desirability towards that behaviour should be and, consequently, the stronger the individual's intention to go ahead and start a business (Van Gelderen et al., 2008).

Multiple studies indicated a strong link between attitude and EI. Most of their findings (Tkachev \& Kolvereid, 1999) revealed that perceived desirability has direct and positive effect on entrepreneurial intentions. That goes to show that people who perceive good opportunities for them to start-up a business, or develop favourable attachment towards high status of entrepreneurs, tend to start their own venture (Xavier et al., 2009). Also, the attitude of students was found to have a significant influence on intention. In fact the findings of scholars revealed a very strong influence of attitude on intention whereby attitude is seen to be a deterministic variable for intention, with every variation in attitude directly leading to a variation in same extent for entrepreneurial intention (Leong, 2008; Scholten et al. 2004; Krueger et al., 2000). This goes to show that the more students value the entrepreneurial career path, the stronger their intentions to be entrepreneurs.

In Nigeria and Malaysia, similar studies were conducted and their findings revealed that there is a positive relationship between attitude and EI, meaning that positive attitude toward self-employment to create a new venture successfully appeared to predict stronger levels of entrepreneurial intention (Inegbenebor and Ogunrin, 2010; Frazier and Niehm, 2006; Dakung \& Katura, 2014). The implication of their finding (Elfving, Brännback and Carsrud, 2009) lies in the fact that if individuals hold positive attitude towards self-employment, they consider entrepreneurship with their overall goals in life and see an opportunity to form entrepreneurial intention and perform an entrepreneurial action. Hence, stemming from TPB (Ajzen, 1991) and the empirical studies, we set down our hypothesis as thus:

H1: There is positive relationship between attitude and entrepreneurial intentions of the disabled students.

\subsection{Discrimination and Entrepreneurial Intention}

Throughout history, disabilities have always been misunderstood and dated back as far as Plato and Aristotle's days (the time of Ancient Greece: 427-347 BC \& Rome: 384-322 BC) when they mentioned that those born deaf become senseless and incapable of reason (Chadwick, 2003). This concept about people with disabilities (PWDs) ran even into World War II when Hitler started mercy killing involving the sick and disabled, which he referred to them as the lives unworthy of living. These ideas set up the stigmas which have been carried throughout history coupled with assumptions that PWDs are helpless dependants. Hence, there has been relatively little interest in them as social beings and contributors to economic development (Chadwick, 2003). For instance, in Tanzania and South Africa, persons with albinism are alienated, ostracized and not seen as normal human beings by other people in the society. The beliefs surrounding them are that they are borne as punishment from God, that it is a curse giving birth to albinos, and that they are immortal and spirits (Stensson, 2008; Blankenberg, 2000). In spite of such discrimination and stigmatization, the disabled have demonstrated full productive capacities, especially in the area of job creation. 
One feature of the literature on entrepreneurs with disabilities is that the reasons for starting their own business are heavily rooted in negative motives (Cooney, 2008). It has been recognized that failure to find a job is a key push factor for disabled people considering self-employment. For example, people who have been disabled from young age may have already experienced disadvantage (discrimination and stigmatization) within the education system due to lack of access to facilities and the full curriculum may want to start their own venture. This perceived or actual discrimination is seen as a major factor that triggers EIs among PWDs (Namatovu et al., 2012; Boylan and Burchardt, 2003; Blanck et al., 2000). Also, discrimination is seen to be an important explanation of the higher rates of self-employment that are found amongst people with disabilities than with non-disabled people because many entrepreneurs with disabilities start their own businesses as a result of the obstacles they encounter like lack of physical accommodations, or the need for a flexible schedule, while searching for a traditional job (Blank et al., 2000; Pagan, 2009; Schur, 2003; Holub, 2001). To that effect, PWDs may wish to become self-employed simply to overcome discrimination in the labour market and also to rebuild their self-esteem (Cooney, 2008; Strauser \& Berven, 2006; Godley, 2005).

Furthermore, findings also provided evidence that PWDs become entrepreneurs because they want to escape from job related challenges. Entrepreneurship is a means of avoiding bad situation and this confirms to other authors' view of seeing entrepreneurial activity as a last choice career path (Makau, 2014; Pagan, 2009; Dubini, 1988). This triggering factor falls under the necessity-driven entrepreneurship where individuals are pushed into self-employment. It has been found that people start business because they face discrimination in looking for job and because they want to increase their social status as stated earlier. PWDs are seen to be in this group since they are the most affected in this regard and in some cases, they are referred to as socially discriminated entrepreneurs (Mishra, 2005; Blank et al., 2000; Pagan, 2009; Schur, 2003; Holub, 2001). In line with the proposition of social disability theory (UPIAS, 1976; Finkkelstein, 1980; Oliver, 1996 \& Corker, 2000), it therefore follows that people with disabilities who are discriminated and excluded from society are seen to be pushed to take the initiative of starting their own enterprise. Hence, we hypothesized as thus:

H2: There is positive relationship between discrimination and entrepreneurial intentions of the disabled students.

\subsection{Perceived Behavioural Control and Entrepreneurial Intention}

Perceived behavioural control refers to the perceived ease or difficulty of performing a behaviour (Ajzen, 1991). This concept deals with the non-volitional elements inherent in all behaviours and thus, reflects past experience, as well as anticipated impediments and obstacles (Ajzen, 2002b). Amongst the various factors influencing entrepreneurial intention, motivation in the form of rewards has been studied (Bird, 1989; Volery, Doss, Mazzarol, and Thein, 1997). The motivational factors can be categorized into intrinsic rewards and extrinsic rewards. Intrinsic rewards refer to the psychological factors focusing on the satisfaction of being one's own boss, being in control of one's own destiny or taking full responsibility for the success of new venture and extrinsic rewards refer mainly to financial gain (Choo and Wong, 2006). While extrinsic goals concentrate on wealth and personal income, intrinsic goals focus on recognition, challenge, autonomy, family security, and excitement (Auken, Fry, and Stephens, 2006). Recent studies utilizing the Valence Model of Expectancy Theory (Brice and Nelson, 2008) confirm a strong relation between intentions to pursue entrepreneurial careers and preference for independence. It represents the desire to be own boss and having autonomy to pursue personal interest. Need for independence is about the control belief, freedom from supervision, rules and bureaucracy, which is an aspect of perceived behaviour control (Reynolds, 1997).

One of the approaches in studying entrepreneurial intention is through demographic factors and human capital (Liñán and Chen, 2009). The traits such as achievement orientation, willingness to take risks, and meeting challenges, are considered indicators of entrepreneurial intentions (Raijman, 2001). People with such attributes are believed to have higher potential in starting new ventures. Such traits can be cultivated more readily when the individual has prior work experience or start-up experience as the increased knowledge gives individuals a better awareness about the existence of alternative career option (Liñán, 2004). Empirical study conducted on Mexican immigrants in Chicago shows that individuals thinking about starting businesses have slightly higher human capital characteristics in level of education, proficiency in English, and some informal self-employment experience (Raijman, 2001). On individual basis, social identification (human value) can influence intention. The extent an 
individual believes in in his/her capability and is being appreciated by other people can impact his/her intention to pursue entrepreneurial occupation (Grundstén, 2004).

As self-efficacy is considered part of the perceived behavioural control, it is important to understand such theory in the entrepreneurial behaviour context (Krueger, et al., 2000). The self-efficacy theory is about an individual's belief in own ability to achieve intended goal through own efforts and actions (Bandura, 1997). Such beliefs can have both positive and negative influence on entrepreneurial intention. Self-efficacy is accumulated through the development of cognitive, social, linguistic and physical skills. Empirical research has shown the impact of self-efficacy on social undertaking, learning of educational tasks, overcoming substance abuse and organizational performance (Sequeira, et al., 2007). In entrepreneurship research, studies have found that self-efficacy influences entrepreneurial intention (Boyd and Vozikis, 1994; Krueger and Brazeal, 1994; Kuehn, 2008; Shane, 2003). Applying the controllability of behaviour with self-efficacy venture creation process, more realistic perceptions on entrepreneurial activity can be expected (Ajzen, 2002). Thus, Entrepreneurial Perception is a component of perceived behaviour control. The hypothesis on perceived behavioural control can be stated as:

H3: There is positive relationship between perceived behavioural control and entrepreneurial intentions of the disabled students.

\section{Methodology}

The study was undertaken to examine discrimination in predicting entrepreneurial intentions of the disabled students in Nigerian tertiary institutions. One may wonder why the choice of this population? It is simply because the concept of disability entrepreneurship is now a subject of great interest all over the world and the disabled are becoming more inclined in running and managing their own ventures. This is possible through preliminary interactions before administering the data collection instrument. About 230 questionnaires were distributed to the respondents (i.e. disabled students of University of Jos, Plateau State University, Plateau State Polytechnic, Federal College of Education Pankshin and College of Education, Gindiri). Data collected were presented using simple descriptive statistical method (percentage) and the hypotheses tested using Structural Equation Model (SEM).

\section{Measurements}

Entrepreneurial Intentions measures were derived modified from Entrepreneurship Intentions Questionnaire (EIs Questionnaire) by Linan \& Chan's (2009). It was measured by utilising a 6-point Likert scale, ranging from 1 (strongly disagree) to 6 (strongly agree). Measures for discrimination were derived from Williams et al., (2008) and Trammell (2010). Attitude scales were adapted and modified from Ajzen (1991) and Liñán and Chen (2009), while measures for Perceived behavioural control were derived from scholarly works of Bandura (1983), Ajzen (1991) and Liñán and Chen (2009). All the scales were measured by utilising a 6-point Likert scale, ranging from 1 (strongly disagree) to 6 (strongly agree) based on previously published studies.

\section{Presentation of Results/Findings}

A total of 211 questionnaires were properly filled and retrieved for this study (the collected questionnaires showed a $97.1 \%$ response rate). However, we discovered missing values (unanswered questions) in the course of coding. The questionnaires were coded, analysed and tested for reliability and validity of instrument. The Cronbach Alpha test was used to check for the reliability of the questionnaire. A value of 0.70 showed that the instrument is reliable and good for further analyses. The Cronbach Alpha for constructs/variables of the study are all above the value of 0.70 . This is shown in table 1.

Table1. Reliability Statistics

\begin{tabular}{|l|l|}
\hline Construct & Cronbach's Alpha \\
\hline Entrepreneurial Intention & .732 \\
\hline Attitude & .829 \\
\hline Discrimination & .765 \\
\hline Perceived Behavioural Control & .894 \\
\hline
\end{tabular}


Discrimination in Predicting Entrepreneurial Intentions of the disabled Students in Nigeria

Table2. Personal Profile

\begin{tabular}{|c|c|c|c|c|c|}
\hline Gender & Male & Female & Total & & \\
\hline & $68 \%$ & $32 \%$ & $100 \%$ & & \\
\hline \multirow[t]{2}{*}{ Age Group } & $16-25$ & $26-35$ & $36-45$ & 46-Above & Total \\
\hline & $59 \%$ & $29 \%$ & $12 \%$ & Nil & $100 \%$ \\
\hline \multirow[t]{2}{*}{ Disability Category } & Crippled & Deaf & Blind & Albinism & Total \\
\hline & $36 \%$ & $23 \%$ & $25 \%$ & $16 \%$ & $100 \%$ \\
\hline \multirow[t]{2}{*}{$\begin{array}{l}\text { How you acquired the } \\
\text { Disability }\end{array}$} & At Birth & Later in Life & Total & & \\
\hline & $46 \%$ & $54 \%$ & 100 & & \\
\hline \multirow[t]{2}{*}{ Course of Study } & Business Related & Non Business Related & Total & & \\
\hline & $23 \%$ & $77 \%$ & $100 \%$ & & \\
\hline
\end{tabular}

Table3. Triggers of Disabled Students' Intentions to Start Business

\begin{tabular}{|c|c|c|c|c|c|c|c|}
\hline & SD & $\mathbf{D}$ & SMWD & SMWA & $\mathbf{A}$ & $\mathbf{S A}$ & Total \% \\
\hline \multicolumn{8}{|l|}{ Entrepreneurial Intention } \\
\hline I am ready to do anything to be an entrepreneur & 6.7 & 12.0 & 10.9 & 18.1 & 27.8 & 26.6 & 100 \\
\hline $\begin{array}{l}\text { I will make every effort to establish my own } \\
\text { business }\end{array}$ & 0.7 & 1.5 & 3.3 & 14.8 & 46.1 & 33.6 & 100 \\
\hline My professional goal is to be an entrepreneur & Nil & 0.4 & 3.0 & 18.5 & 42.4 & 35.7 & 100 \\
\hline $\begin{array}{l}\text { I intend to start my own business within the next } \\
\text { two years }\end{array}$ & 19.6 & 11.8 & 8.7 & 14.8 & 30.6 & 14.5 & 100 \\
\hline $\begin{array}{l}\text { I intend to start my own business within the next } \\
\text { five years }\end{array}$ & 6.0 & 7.0 & 3.4 & 10.5 & 12.0 & 61.1 & 100 \\
\hline $\begin{array}{l}\text { I intend to start my own business within the next } \\
\text { ten years }\end{array}$ & 24.7 & 17.3 & 5.0 & 13.6 & 18.8 & 20.6 & 100 \\
\hline \multicolumn{8}{|l|}{ Attitude } \\
\hline $\begin{array}{l}\text { Among the various career options, I would be } \\
\text { anything but an entrepreneur }\end{array}$ & 9.6 & 8.1 & 10.3 & 12.2 & 30.3 & 29.4 & 100 \\
\hline $\begin{array}{l}\text { Being an entrepreneur would give me great } \\
\text { satisfaction }\end{array}$ & Nil & 0.7 & 1.8 & 13.7 & 42.1 & 41.7 & 100 \\
\hline $\begin{array}{l}\text { Being an entrepreneur implies more advantages } \\
\text { than disadvantages to me }\end{array}$ & 1.1 & 0.7 & 2.6 & 12.5 & 43.5 & 39.5 & 100 \\
\hline $\begin{array}{l}\text { A career as an entrepreneur is totally attractive to } \\
\text { me }\end{array}$ & 0.6 & Nil & 3.8 & 9.6 & 52.4 & 33.6 & 100 \\
\hline \multicolumn{8}{|l|}{ Discrimination } \\
\hline $\begin{array}{l}\text { I have been treated with less respect than other } \\
\text { people }\end{array}$ & 2.3 & 1.8 & 0.5 & 18.3 & 42.4 & 34.7 & 100 \\
\hline $\begin{array}{l}\text { I have received poorer services than other people } \\
\text { at restaurants, school or stores }\end{array}$ & 0.7 & Nil & 2.5 & 12.5 & 48.5 & 35.8 & 100 \\
\hline $\begin{array}{l}\text { I have realized that the best option for me is set up } \\
\text { my own business rather than look for job }\end{array}$ & Nil & 1.1 & 1.1 & 16.9 & 49.4 & 31.5 & 100 \\
\hline $\begin{array}{l}\text { My disability will not stop me from achieving my } \\
\text { goal in life }\end{array}$ & Nil & 1.4 & 12.5 & Nil & 46.5 & 39.6 & 100 \\
\hline $\begin{array}{l}\text { I will work harder to proof to the world that there } \\
\text { is ability in disability }\end{array}$ & 3.7 & Nil & 2.6 & 18.1 & 64.5 & 29.2 & 100 \\
\hline $\begin{array}{l}\text { People have acted as if they are afraid of my } \\
\text { disability }\end{array}$ & 8.8 & 4.4 & 11.1 & 18.1 & 28.6 & 29.2 & 100 \\
\hline $\begin{array}{l}\text { I am trying my best to liberate (escape) myself } \\
\text { from life's obstacles and depending on other } \\
\text { persons }\end{array}$ & 14.8 & 1.8 & 3.0 & 0.4 & 52.1 & 27.6 & 100 \\
\hline \multicolumn{8}{|l|}{ Perceived Behavioural Control } \\
\hline $\begin{array}{l}\text { I can always manage to solve different problems if } \\
\text { I try hard enough }\end{array}$ & 1.1 & 2.6 & 2.6 & 18.1 & 64.5 & 29.2 & 100 \\
\hline $\begin{array}{l}\text { It is easy for me to stick to my aims and } \\
\text { accomplish my goals }\end{array}$ & 0.7 & 1.4 & 1.5 & 16.6 & 41.3 & 38.4 & 100 \\
\hline $\begin{array}{l}\text { Thanks to my resourcefulness, I know how to } \\
\text { handle unforeseen situations }\end{array}$ & 11.0 & 4.5 & 9.8 & 17.1 & 28.5 & 29.3 & 100 \\
\hline $\begin{array}{l}\text { I can solve most problems if I invest the necessary } \\
\text { effort }\end{array}$ & 0.4 & 1.5 & 3.3 & 14.8 & 46.1 & 33.6 & 100 \\
\hline $\begin{array}{l}\text { If I am in a fixed, I can usually think of something } \\
\text { to do }\end{array}$ & Nil & 0.4 & 3.0 & 18.5 & 42.4 & 35.8 & \begin{tabular}{|l|l}
100 \\
\end{tabular} \\
\hline
\end{tabular}

Note: Disabled Students' opinions are expressed in a 6-point scale (1- strongly disagree (SD), 2- disagree (D), 3 - somewhat disagree (SMWD), 4 - somewhat agree (SMWA), 5 - agree (A) and 6 - strongly agree (SA) 


\section{INTERPRETATIONS}

Table 2 shows the profile of the disabled students used in this analysis. Among the 230 students from the sample, $68 \%$ are male students, $59.4 \%$ fall within the age bracket of $16-25$ years, $36.2 \%$ of them have crippled form of disability, 54\% acquired the disabilities later in life and $77 \%$ are studying for a non-Business programmes in the various higher institutions of learning.

From table 3 above, it could be seen that the item, "I intend to start my own business within the next five years" under the entrepreneurial intention construct has the highest percentage $(61.1 \%)$. By implication, it means then that the disabled students are ready to start their own businesses in the next two years (i.e. around 2020). Discrimination as a push factor is crucial in determining entrepreneurial intentions. Hence, $52.1 \%$ of the respondents observed that they are trying their best to liberate (escape) themselves from life's obstacles and depending on other persons. To ascertain their attitudes towards entrepreneurship, 52.4\% of the respondents observed that their careers as entrepreneur is totally attractive to them, signifying positive attitudes. Also, the results in the table indicated that $64.5 \%$ which constitutes the majority of the respondents said that based on their perceived behavioural control, they can always manage to solve different problems if they try hard enough.

Table4

\begin{tabular}{|c|c|c|c|c|}
\hline Hypotheses & Path & Estimate & P-Value & Remark \\
\hline $\begin{array}{l}\text { H1: There is positive relationship between } \\
\text { attitude and entrepreneurial intention of disabled } \\
\text { students }\end{array}$ & $\mathrm{ATT} \longrightarrow \mathrm{EI}$ & $3.27 * *$ & 0.00 & Accepted \\
\hline $\begin{array}{l}\mathrm{H} 2 \text { : There is positive relationship between } \\
\text { discrimination and entrepreneurial intention of } \\
\text { disabled students }\end{array}$ & $\mathrm{DSC} \longrightarrow \mathrm{EI}$ & $0.61^{*}$ & 0.04 & Accepted \\
\hline $\begin{array}{l}\text { H3: There is positive relationship between } \\
\text { perceived behavioural control and } \\
\text { entrepreneurial intention of disabled students }\end{array}$ & $\mathrm{PBC} \longrightarrow \mathrm{EI}$ & $1.53 * *$ & 0.00 & Accepted \\
\hline
\end{tabular}

Significant at 10\%; *Significant at 5\%; **Significant at 1\%

\section{DisCuSSION}

Table 4 provides the hypotheses results of the influence of attitude, discrimination and perceived behavioural control factors on disabled students' entrepreneurship intentions. Attitude towards entrepreneurship is positively related $(\mathrm{B}=3.27, p<0.01)$ to entrepreneurial intention. This finding confirms our hypothesis 1 that there is a positive relationship between attitude and entrepreneurial intentions of the disabled students. The result supports the findings of scholars (Inegbenebor \& Ogunrin, 2010; Elfving, Brännback and Carsrud, 2009; Xavier et al., 2009; Leong, 2008; Frazier and Niehm, 2006; Scholten et al. 2004; Krueger et al., 2000; Tkachev \& Kolvereid, 1999) which revealed a very strong influence of attitude on intention. In addition, the result for $\mathrm{H} 2$ is accepted since it reveals a positive and significant relationship $(\mathrm{B}=0.61 ; \mathrm{p}<0.05)$ between discrimination and entrepreneurial intentions of disabled students. This result is in tandem with the previous findings of scholars (Cooney, 2008; Strauser \& Berven, 2006; Godley, 2005; Boylan and Burchardt, 2003; Blanck et al., 2000). Importantly, discrimination of the disabled students whether at school or in the society is positively related to entrepreneurial intention, confirming our Hypothesis 2 that disabled students who have been discriminated will have higher level of entrepreneurial intention. Finally, H3 indicated a positive and significant relationship $(\mathrm{B}=1.53 ; p<0.01)$, hence is accepted. This goes to show that the direct effect of perceived behavioural control on entrepreneurial intention of the disabled students is significant as documented by Kuehn (2008); Shane (2003); Ajzen (2002) Boyd and Vozikis (1994); Krueger and Brazeal (1994).

\section{Conclusions}

The significant and positive relationship between attitude, discrimination and perceived behavioural control shows that discrimination predicts entrepreneurial intentions of disabled students. Studying entrepreneurial intention is crucial today since the impact of entrepreneurship activities on job creation and the economic growth of a country are recognized all over the world. The major result from the analysis revealed that there is a positive relationship between attitude, discrimination and perceived behavioural control and entrepreneurial intention of the disabled students. Furthermore, 
most of the disabled students confirmed that in spite of stigmatization and discrimination, the career of becoming entrepreneurs is totally attractive to them, signifying positive attitudes and so they intend starting businesses in the next five years (i.e. around 2020).

\section{THEORETICAL IMPLICATIONS}

The study is based on multi-theoretical review that contributed to theory development in the field of entrepreneurship by empirically investigating discrimination as a predictor of EIs of disabled students. The first notable theoretical implication of this study is its contribution to the ongoing entrepreneurial intention debate. From the foregoing we assert that in order to understand how discrimination predicts EI of disabled students, there must be to inclusionary practices/programs as a more effective way by higher educational institutions of learning (HEIs) in Nigeria and the society at large to influence disabled students' entrepreneurial intention and encourage venture creation activity on campuses and after their graduation. Previous researchers have acknowledged the fact that discrimination, being a push factor is crucial in influencing EI of persons with disabled. For example, scholars (Blank et al., 2000; Pagan, 2009; Schur, 2003; Holub, 2001) have established PWDs are motivated to start their own businesses as a result of the obstacles they encounter like lack of physical accommodations, or the need for a flexible schedule, while searching for a traditional job. The second theoretical implication relates to the importance attached to attitude and perceived behavioural control. Empirical evidence (Inegbenebor \& Ogunrin, 2010, Xavier et al., Kuehn, 2008; Shane, 2003; Ajzen, 2002) has suggested that attitude and perceived behavioural control influence EI.

\section{METHODOLOGICAL IMPLICATIONS}

One major methodological implication is the role of multi methods approach in predicting EIs. This study attempted to build upon prior works in the area of EIs by combining both quantitative and qualitative data to predict EIs of disabled students. This will provide terminological and conceptual clarity and coherence (Tashakkori \& Teddlie, 1998). Support for the multi method and mixed designs is derived from extant literature that reveals that mixed designs remains largely unstudied (Newman \& Benz, 1998; Tashakkori \& Teddlie, 1998).

\section{Managerial and Policy Implications}

The first major managerial implication concerns the recruitment of discrimination, attitude and perceived behavioural control influence on EIs. Tertiary institutions in Nigeria may want to hire and train lecturers who are resourceful and have the skills/competence in teaching entrepreneurship that will enhance the intentions of disabled students in starting a venture. Another managerial implication relate to providing a conducive atmosphere that fosters lifelong learning for disabled students by the Nigerian tertiary institutions.

\section{Limitations OF THE STUDY}

The study is only restricted to Plateau State - Nigeria. Further research could be conducted to cover all the States in the North-Central region of Nigeria. Also, this study employed the cross-sectional approach. A longitudinal approach should be employed to study the trend over a period of at least two years. Finally, the three (3) factors identified as predictors of entrepreneurship intentions may not be sufficient enough in explaining the phenomenon. Hence, there are other factors that may contribute in influencing entrepreneurship intentions of disabled students that were not part of this study.

\section{REFERENCES}

Ajzen, I. (1991). The Theory of Planned Behaviour. Organizational Behaviour and Human Decision Processes, 50:179-211.

Ajzen, I. (2002). Perceived behavioural control, self-efficacy, locus of control, and the theory of planned behaviour. Journal of Applied Social Psychology, 32(4), 665-683.

Ajzen, I. and Fishbein, M. (1980). Understanding attitudes and predicting social behaviour. Eaglewood Cliffs. NJ: Prentice-Hall.

Akhuemonkhan, I. A, Raimi, L, \& Sofoluwe, A. (2013). Entrepreneurship Education and Employment Stimulation in Nigeria. Journal of Studies in Social Sciences. 3:(1), 55-79

Armitage, C. J. and Conner, M. (2001). Efficacy of the theory of planned behaviour: A meta-analytic review. British Journal of Social Psychology, 40(4):471-99. 
Asch, A. and Fine, M. (1988). Introduction: Beyond pedestals. In M. Fine \& A. Asch (Eds.), Women with disabilities: Essays in psychology, culture and politics (pp. 1-37). Philadelphia: Temple University Press.

Auken, H.V., Fry, F.L. and Stephens, P. (2006). The Influence of role models on entrepreneurial intentions. Journal of Developmental Entrepreneurship, 11(2), 157-167.

Autio, E., Keeley, R., Klofsten, M. and Ulfstedt, T. (1997). "Entrepreneurial Intent among Students: Testing an Intent Model in Asia, Scandinavia and in the USA." Frontiers of Entrepreneurship Research. Wellesley, MA: Babson College.

Bandura, A. (1977). Self-efficacy: Toward a unifying theory of behavioural change. Psychological Review, 84, 191-215.

Barringer, B. R. and Ireland, R. D. (2010). Entrepreneurship: successfully launching new ventures (3rd ed.). New Jersey: Pearson.

Bartov, E, F. A. Gul, J. and Tsui, S. L. (2000). "Discretionary-accruals models and audit qualifications," Journal of Accounting and Economics, 30:421-52.

Basu, S. (1997). The Conceptual Difference between Incomplete Information and Asymmetric Information: A study of Business Behaviour in The Presence of Uncertainty. Macquiarie University, Sydney

Bird, B. (1988). Implementing Entrepreneurial Ideas: The Case for Intention. The Academy of Management Review, 13(3): 442-453.

Blanck, P. D., Sandler, L. A., Schmeling, J. L. and Schartz, H. A. (2000). 'Emerging workforce of entrepreneurs with disabilities: preliminary study of entrepreneurship in Iowa', Iowa Law Review, 85:1583-1668.

Blankenberg, N. (2000). "That Rare and Random Tribe: Albino Identity in South Africa".

Bonanno, G. A., Maren Westphal, M. and Mancini, A. D. (2010). Resilience to Loss and Potential Trauma. CP07CH01-Bonanno ARI 15 November 2010 15:53

Boyd, N.G. and Vozikis, G. S. (1994). 'The influence of self-efficacy on the development of entrepreneurial intentions and actions', Entrepreneurship Theory and Practice, Summer:63-74

Boylan, A. and Burchardt, T. (2003). Barriers to Self-Employment for Disabled People. Small Business Service, London.

Brice, J.J., and Nelson, M. (2008). The impact of occupational preferences on the intent to pursue an entrepreneurial career. Academy of Entrepreneurship Journal, 14(1), 13-36.

Chadwick, P. (2003). Disability social history project. Retrieved from http://www.disabilityhistory .org/timeline_new.html

Choo, S. and Wong, M. (2006). 'Entrepreneurial Intention: Triggers and Barriers to New Venture Creation in Singapore', Singapore Management Review, Vol. 28, No. 2, pp. 47-64.

Cooney, T. M. (2008). Entrepreneurs with Disabilities: Profile of a Forgotten Minority. Irish Business Journal, 4(1):119-129.

Corker, M. (2000). Disability politics, language planning and inclusive social policy. Disability and Society, 15(3):445 461.

Corker, M. (2000). The U.K. Disability Discrimination Act: Disabling language, justifying inequitable social participation. In L. P. Francis, \& Silvers, A. (Eds.), Americans with disabilities: Exploring implications of the law for individuals and institutions (pp. 357-370). New York: Routledge.

Dakung, R. J. and Katura, J. I. (2014). Entrepreneurial Mind-Set among Female University Students: A Study of University of Jos Students, Nigeria. Chinese Business Review, 13(5): 320-332.

Davidsson, P. (1995). 'Determinants of Entrepreneurial Intentions, Proceedings RENT XI Workshop. Piacenza, Italy.

Dell, M. S. (2008). An investigation of undergraduate student self-employment intention and the impact of entrepreneurship education and previous entrepreneurial experience. Doctor of Philosophy, School of Business University Australia. Disabilities in International Development Programs.

Dhose, D. and Walter, S. G. (2010). The role of entrepreneurship education and regional Context in forming entrepreneurial intentions. Working Paper present at Document de treball de l'IEB 2010/18. 
Dubini, P. (1988). The influence of motivations and environment on business start-ups: Some hints for public policies. Journal of Business Venturing 4:11-26.

East Midlands Development Agency (2009). Scoping Study into the Business Support Needs of Disabled Entrepreneurs in the East Midlands Final Report.

Egunsola, A. O. E. Dazala, I. U. and Daniel, J. D (2012). Entrepreneurship Education and Attitude of Undergraduate Students to Self-employment in Mubi, Adamawa State, Nigeria. Journal of Education and Practice, 3(8).

Elfving, J., Brännback, M. and Carsrud, A. (2009). Toward A Contextual Model of Entrepreneurial Intentions. International Studies in Entrepreneurship, 24, Part 1, 23-33.

Emmanuel, O. S., Adejoke, K. B., Olugbenga, O. V., and Olatunde, O. L. (2012). Entrepreneurial Intention among Business and Counselling Students in Lagos State University Sandwich Programme, Journal of Education and Practice, 3(14).

Eppen, G. D; Gould, F. J; Schmidt, C. P; Moore, J. H. and Weatherford, L. R. (1998). Introductory Management Science: Decision Modelling with Spreadsheets, $5^{\text {th }}$ edn, Prentice Hall, Upper Saddle River.

Finkelstein, V. (1980). Attitudes and disabled people. New York: World Rehabilitation Fund.

Frazier, B. J. and Niehm, L. S. (2006). Predicting the entrepreneurial intentions of non-business majors: A Preliminary Investigation. Paper presented at the USASBE/SBI Conference, Tucson, AZ, January 14-17.

Godley, A. (2005). The Emergence of Ethnic Entrepreneurship. Princeton University Press, Princeton, NJ.

Grundsten, H. (2004). "Entrepreneurial Intention and Entrepreneurial Environment. A Study of Technology- Based New Venture Creation", Doctoral dissertation. Helsinki University of Technology,Finland.

Harper,M. and Momm, W. (1989). Self-Employment for Disabled People: Experiences from Africa and Asia. International Labour Office.

Holub, T.(2001). Entrepreneurship among people with Disabilities. Adjunct ERIC Clearinghouse on Entrepreneurship Education, Los Angeles, CA.

Inegbenebor, A.U. and Ogunrin, F. O. (2008) Entrepreneurial attitudes and intentions among Nigerian undergraduates. Ghana Journal of Development Studies, 7(2).

Ismail, M; Khalid, S.A; Othman, M; Jusoff, K; Abdul Rahman, N; Mohammed, K.M and Shekh, R.Z. (2009). Entrepreneurial intention among Malaysian undergraduates. International Journal of Business and Management, 4(10):54-60.

Kautonen,T., Down, S. and Minniti, M. (2013). Ageing and Entrepreneurial Preferences, DOI 10 1007/s11187-013-9489-5.

Kolvereid. L. and Isaksen. E. (2006). New business start-up and subsequent entry into selfemployment. Journal of Business Venturing, 21(6):866-885.

Kritikos, A. S (2014). Entrepreneurs and their impact on jobs and economic growth: Productive entrepreneurs can invigorate the economy by creating jobs and new technologies, and increasing productivity: DIW Berlin, University of Potsdam, and IZA, Germany.

Krueger, N. F. and Brazeal, D.V. (1994). 'Entrepreneurial potential and potential entrepreneurs', Entrepreneurship Theory and Practice, Spring: 91-104.

Krueger, N. F. Jr., Reilly, M. D. and Carsrud, A. L. (2000). Competing Model of Entrepreneurial Intentions. Journal of Business Venturing, 15(5-6):411-432.

Kuehn, K.W. (2008). Entrepreneurial Intentions Research: Implications for Entrepreneurship Education. Journal of Entrepreneurship Education, 11, 87-98.

Lamb, B. (2009). Report to the Secretary of State on the Lamb Inquiry Review of SEN and Disability Information.

Lee, S. H. and Wong, P. K. (2004). An exploratory study of technopreneurial intentions: a career anchor perspective. Journal of Business Venturing, 19:7-28.

Leong, C. K. (2008). Entrepreneurial Intention: An Empirical Study among Open University Malaysia Students. Dissertation, Open University Malaysia Centre for Graduate Studies. 
Liñán, F. (2004). Intention-based models of entrepreneurship education. Piccolla Impresa/Small Business, 3:11-35.

Liñán, F. and Chen, Y. W. (2009). Development and cross-cultural application of a specific instrument to measure entrepreneurial intentions. Entrepreneurship Theory and Practice, 33(3) (in press).

Makau, R. K. (2014). Disability and entrepreneurship: factors that influence the Entrepreneurial intentions of visually impaired students at the Machakos technical institute for the blind (Unpublished).

Mishra, Atul. (2005). Entrepreneurial Motivations in Start-up and Survival of Micro- and Small Enterprises in the Rural Non-Farm Economy. Journal of Small Business \& Entrepreneurship, (3):289-326.

Namatovu, R; Dawa, S; Mulira, F and Katongole, C. (2012). Entrepreneurs with disability in Uganda, Makerere University Business School, ICBE-RF NO.31/12. Accessed on 25/September/2013 www.trustafrica.org/icbe Nascent Entrepreneurs. "Journal of Business Venturing, 20. 121.

Newman, I. and Benz, C. R. (1998). Qualitative-Quantitative Research Methodology - Exploring the Interactive Continuum. Carbondale, IL: Southern Illinois University Press, pp. 9, 65 - 67.

Olayinka, C (2010). Turkey to partner on Job Creation in Initiations. Lagos: The guardian Newspaper Tuesday 9 February, 2010.

Oliver, M. (1990). The politics of disablement. Basingstoke: Macmillan.

Pagán, R. (2009). Self-employment among people with disabilities: Evidence for Europe. Disability \& Society, 24(2):217-229.

Raijman, R. (2001). Determinants of entrepreneurial intentions: Mexican immigrants in Chicago. The Journal of Socio-Economics 30, 393-411.

Reitan, B. (1996). Entrepreneurial intentions: a combined models approach. 9th Nordic Small Business Research Conference, Lillehammer, Norway, 29-31 May.

Reynolds, P. D. (1997). "Who Starts New Firms? Preliminary Explorations of Firms-in-Gestation." Small Business Economics: 449-462.

Scholten, V., Kemp, R. and Omta, O. (2004). Entrepreneurship for life: The entrepreneurial intention among academics in the life sciences. Paper presented at the European Summer University Conference 2004, Enschede. The Netherlands.

Schur, L. (2003). Barriers or Opportunities? The Causes of Contingent and Part- Time Work among People with Disabilities. Industrial Relations, Vol.42, 589-622.

Sequeira, J., Mueller, S. L. and McGee, J. E. (2007). 'The influence of social ties and self-efficacy in forming entrepreneurial intentions and motivating nascent behaviour', Journal of Developmental Entrepreneurship, 12(3): 275-293.

Shane, S.A. (2003). A general theory of entrepreneurship: The individual opportunity nexus. Cheltenham, UK: Edward Elgar.

Sheeran, P., Orbell, S. and Trafimow, D. (1999). Does the Temporal Stability of Behavioural Intentions Moderate Intention-behaviour and Past Behaviour-Future Behaviour Relations? Personality and Social Psychology Bulletin, 25(6):721-730.

Stensson, E. (2008). The social stratification of albinos in Tanzania - a case study from Babati. Södertörn University College| Institution of School of Life Sciences Bachelor's Thesis 15 ECTS/Development and International Cooperation.

Strauser, D. R. and Berven, N. L. (2006). Construction and field testing of the job seeking selfefficacy scale. Rehabilitation Counselling Bulletin, 49(4), 207-218. Retrieved from http ://web .ebscohost.com/ehost/pdfviewer/pdfviewer?sid=4b3d2c9d-27f0.

Tashakkori, A. and Teddlie , C. H . (1998) Mixed Methods: Combining Qualitative and Quantitative Approaches. Thousand Oaks, CA: Sage Publications

Thompson, E. R. (2009). Individual entrepreneurial intent: Construct clarification and development of an internationally reliable metric. Entrepreneurship Theory and Practice, May, 669-694.

Tkachev. A. and Kolvereid. L. (1999). Self- employment intention among Russian students. Entrepreneurship \& Regional Development, 11(3):269-280. 
Tounés, A. (2006). Students ${ }^{\text {ee }}$ Entrepreneurial Intentions in France. Paper presented at the Annual Academy of Management Conference; Atlanta, Georgia. 11 - 16 August.

Udo, B. (2015). Nigeria adopts new unemployment guideline; may categorize millions 'employed' without jobs.

UPIAS, (1976). Fundamental Principles of Disability: Union of the Physically Impaired Against Segregation, London.

Valliere, D. and R. Peterson (2009). "Entrepreneurship and economic growth: Evidence from emerging and developed countries." Entrepreneurship \& Regional Development, 21 (5-6):459480.

Van Gelderen, M., Brand, M, Van Praag, M., Bodewes, W., Poutsma, E. and Van Gils, A. (2008). "Explaining Entrepreneurial Intentions By Means of the Theory of Planned Behaviour.

Viriri, P. and Makurumidze, S. (2014). Engagement of disabled people in Entrepreneurship Programmes in Zimbabwe, Journal of Small Business and Entrepreneurship Development, 2(1):01-30.

Volery, T., Doss, N., Mazzarol, T., and Thein, V. (1997), 'Triggers and Barriers Affecting Entrepreneurial Intentionality: The Case of Western Australian Nascent Entrepreneurs', 42nd ICSB World Conference, June 21-24, San Francisco.

WHO (2014). Disability Draft WHO global disability action plan 2014-2021: Better health for all people with disability; sixty-seventh world health assembly A67/16, Provisional agenda item 13.3

Williams, D. R., González, H.M., Williams, S., Mohammed, S. A., Moomal, H. and Stein, D. J. (2008). Perceived Discrimination, Race and Health in South Africa: Findings from the South Africa Stress and Health Study. Social Science and Medicine, 67:441-452.

Xavier, R., Ahmad Z., Dewi, A. S., Leilanie, M. N., Mohar, Y. A., Mohd Hanif, H. S. S. and Saad, N. (2009). The Global Entrepreneurship Monitor (GEM) Malaysian Report, 2009. Retrieved June 23, 2012, from http://www.gemconsortium.org/docs/download/753.

Yoloye, T. W. (2008), "Education reforms and attainment of Vision 2020 goals in Nigeria", Nigerian Tribune, Wednesday, 10 September.

\section{AUTHORS' BIOGRAPHY}

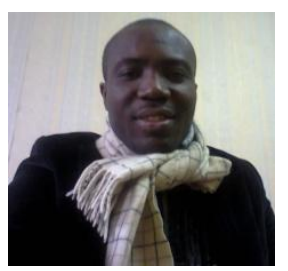

Dakung Reuel Johnmark is a lecturer in the Department of Business Administration, University of Jos-Nigeria. He is currently a doctoral student in entrepreneurship at the Makerere University Business School (MUBS) Kampala, Uganda. His research interest is in strategic management, marketing, entrepreneurship education among the minority groups (disabled students, prison inmates, internally displaced persons) and religious entrepreneurship.

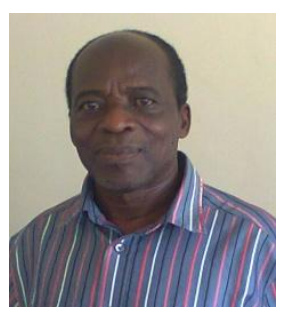

Professor J. C. Munene is a professor of Organizational and Industrial Psychology at Makerere University Business School. He occupies a competence development niche in Human Resource Management, Organizational and Institutional development with an extensive experience in the Public sector, NGO Sector, Public Enterprise/Authority Sector and Private Sector in Uganda where he has conducted major competence based human resources interventions. Among the assignments he has undertaken in Uganda include restructuring Uganda Revenue Authority, Uganda Communications Commision, Makerere University Business School, Baylor College of Medicine, Save the Children Uganda, Uganda Medical Stores and other major employing organizations in the Country. He is currently the PhD coordinator at the Makrere University Business School (MUBS). 